\title{
Forensilc Entomology \\ Ultrastructural studies of sensilla in one fly of forensic importance
}

\author{
Cesar Carriço ${ }^{1,2} \bowtie\left(\right.$, Rebecca Leal Caetano ${ }^{1,3}$, Thalyta Maria de Souza Nascimento ${ }^{2}$ \\ \& Zeneida Teixeira Pinto ${ }^{1}$
}

1. Instituto Oswaldo Cruz/Fundação Oswaldo Cruz (IOC/FIOCRUZ), Laboratório de Educação em Ambiente e Saúde, Brazil. 2. Instituto Brasileiro de Medicina de Reabilitação-IBMR/Laureate International Universities. 3. Universidade Estácio de Sá (UNESA).

\section{EntomoBrasilis 13: e849 (2020)}

\section{Edited by:}

William Costa Rodrigues

Article History:

Received: 16.iv.2019

Accepted: 17. viii. 2020

Published: 26.viii.2020

\section{Corresponding author:}

Zeneida Teixeira Pinto

७zeneida@ioc.fiocruz.br

Funding agencies:

\&ithout funding declared

\begin{abstract}
Taxonomic identification is essential in the field of forensic entomology. Insects are important in the decomposition of cadavers. The flies are generally attracted to cadavers and one of the most important contributions is to estimate the postmortem interval. The scanning electron microscopy (SEM), which allows rapid and accurate identification of different species of forensics flies, has been highlighted as it allows better visualization of the external morphology of immature and some adults. The purpose of this study was to examine in details the morphological aspects of sensilla on the antennae of female and male of Xanthacrona bipustulata Wulp using SEM, since many of them could not be observed just by the use of light microscopy.
\end{abstract}

Keywords: Acalyptratae; Arthropod; Brazil; Morphology; Scanning Electron Microscopy.

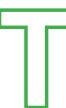

The flies of the family Ulidiidae measure around 2 to 14 $\mathrm{mm}$, usually with a dark and yellow coloration. There are 716 species differentiated in 113 genera (KAMENEVA et al. 2010; TEPEDINo et al. 2017). Most species of this family are saprophagous, but some species have developed the phytophagous habit. The larval and adult stages can feed on a variety of vegetables. Some adults present in this family are attracted by organic matter in the process of decomposition as leaves, fruits, trunks, carcasses and feces (SOUZA \& LINHARES 1997; MARCHIORI \& SILVA 2001). The presence of Ulidiidae species in animal carcasses is rare, the exudates from decaying carcasses could serve as substrate for the development of the larvae, which are usually found in decaying plant material (MoretTl et al. 2008).

Ultrastructure studies using Scanning Electron Microscopy (SEM) have been extensively conducted to clarify some structures on Hexapoda: Lopes et al. (2002) found two types of basiconic sensilla on antennae of Phoracantha semipunctata (Fabricius) (Coleoptera); SukontAson et al. (2004) studied the antennal sensilla of the families Calliphoridae, Sarcophagidae and Muscidae (Diptera); NAscIMENTO et al. (2013) who described, the antennae sensilla of Melipona scutellaris Latreille (Hymenoptera); Goyal et al. (2011) described the egg, larval and pupal stages of three species of the Ulidiidae family: Chaetopsis massyla (Walker), Euxesta eluta Loew and Euxesta stigmatias Loew; ZHANG et al. (2013a) described the sensilla on antennae and maxillary palps of the adults of Lispenei mongola Tian et Ma and observed three types of sensilla (trichoidea, basiconic and chaotic) distributed in these sensorial organs; ZHANG et al. (2013b) observed three types of sensilla (microtrichia, basiconic and trichoidea) on the flagellum of the adults of Fannia scalaris (Fabricius) and Fannia canicularis (Linnaeus); CARRIço et al. (2015) describe sensilla on antennae of the adults of Ophyra albuquerquei
Lopes and Ophyra aenescens (Wiedemann) and observed four types of sensilla distributed on theses organs (microtrichia, basiconic, chaetic and trichoidea); Pezzl et al. (2016) observed six types of sensilla (microtrichia, basiconic, clavate, chaotic, styloconic and trichoidea) on antennae and maxillary palps of the adults of Sarcophaga tibialis Macquart; CARRIço et al. (2017) described the antennae, maxillary palps and Terminalia of males of Peckia (Peckia) chrysostoma (Wiedemann) and observed three types of sensilla (microtrichia, basiconic and trichoidea) distributed in theses sensorial and reproductive organs; CaEtano et al. (2018) analyzed the aspects of the sensilla on antennae and maxillary palps of Mesembrinella bellardiana Aldrich; Mesembrinella bicolor (Fabricius) and Mesembrinella semihyalina Mello and observed four types of sensilla (microtrichia, basiconic, clavete and trichoidea) distributed in theses sensorial organs.

An ultrastructure analysis of the morphological aspects of sensilla on the antennae of $X$. bipustulata have not been performed yet. The purpose of this study was to examine in details these sensorial organs on the aforementioned species to help increase the anatomical database.

\section{MATERIAL AND METHODS}

This research was carried out through the cooperation of "Fundação Oswaldo Cruz" (FIOCRUZ) and "Instituto Samambaia de Ciências Ambientais e Ecoturismo" (ISCAE), process number 07/2018.

The flie $X$. bipustulata was obtained from one carrion of Oryctolagus sp and the collections were performed daily, during january of 2018, in an Atlantic rainforest fragment at "Instituto Samambaia de Ciências Ambientais e Ecoturismo" (ISCA) - Petrópolis, Rio de Janeiro, Brazil (22 $46^{\prime} 90^{\prime \prime} \mathrm{S}$ and 
$43^{\circ} 14^{\prime} 82^{\prime \prime}$ W). Number authorization for scientific research ICMBio/SisBio ("Instituto Chico Mendes de Conservação da Biodiversidade/Sistema de Autorização e Informação em Biodiversidade") was 54279.

Specimens were properly identified following Brown et al. (2009). The terminologies of adult's flies used in this study followed Meloo (2003) and Kosmann et al. (2013), the classification of sensilla followed by SetzU et al. (2011); ZHANG et al. (2013a, b); CARRIço et al. (2015) and CAETANo et al. (2018).

The heads were dissected from one male and five females under dissecting microscope. Then, these structures were processed for SEM examination by transferring to $2.5 \%$ of glutaraldehyde mixture in phosphate buffered saline (PBS) for $24 \mathrm{~h}$. Afterwards, specimens were rinsed twice with PBS during 10-minute- intervals and post fixed with $1 \%$ of osmium tetroxide at room temperature for 3 days. This post fixation step was carried out under a well-ventilated fume hood. The flies were then rinsed twice with PBS and dehydrated in an increasing graded series of ethanol $(30,50$, 70, 80 and 90\%) for 12 h during each step. Thereafter, flies were placed in absolute alcohol, followed by a treatment in absolute acetone. On the next step, the specimens were subjected to critical point drying and they were later placed on metallic supports, coated with a thin gold layer (20-30 $\mathrm{nm}$ ) and examined under JEOL 6390LV scanning electron microscope (SEM) (Akishima, Tokyo, Japan).

\section{RESULTS}

SEM observations of the head of male and female of $X$. bipustulata revealed a pair of antennae, frontally situated, between the large compound's eyes (Figure 1). Antenna morphology consisting in three segments: the first called scape (Sc), the second pedicel (Pe) and a third flagellum observed in female composed of a seta called arista (Ar) located laterally and an enlarged basal flagellomere (Fn) (Figure 1). All antennal segments in this species have sensilla.

Male: The scape is densely covered by microtrichia, and only one type of sensilla was observed: eight-sensilla chaetica (Ch I) of similar length and organized in a single row (Figure 2A). The surface of the pedicel is covered by microtrichia similar to those found in the scape and presents two types of chaetica sensilla (Ch I and ChII). The first type (Ch I) is represented by 14 bristles, similar to those found in the scape. The second type (Ch II) is represented by a single bristle located in the distal region (Figure 3A).
Female: The scape is densely covered by microtrichia, and only one type of sensilla was observed: eight-sensilla chaetica (Ch I) of similar length and arranged in a single row (Figure 2B). The surface of the pedicel is covered by microtrichia similar to those found in the scape and presents two types of chaetica sensilla (Ch I and Chll). The first type (Ch I) is represented by 15 bristles, similar to those found in the scape. The second type (Ch II) is represented by a single bristle located in the distal region (Figure $3 \mathrm{~B}$ ). The flagellum is the largest segment of the antenna and numerous sensilla are found in this segment. Arising closed to the base of the first flagellomere on its dorsolateral surface is the arista, which is composed of two segments (I-II) (Figure 4A). The Fn is densely covered by microtrichia similar to those found in the scape and pedicel. Among the microtrichia has a type of sensilla: trichoidea (tr) (Figure 4B).

\section{DISCUSSION}

The ultrastructure of the antennae of Ulidiidae species using SEM are limited in the literature, theses sensorial structure have been performed, such as: SUKONTASON et al. (2006) described the ultrastructure of the adhesive device in Sarcophaga (Liosarcophaga) Dux Thomson showing the smooth surface and their implication as mechanical carriers of pathogens; Goyal et al. (2011) described the egg, larval and pupal stages of three species of the Ulidiidae family: C. massyla, E. eluta, and E. stigmatias and Pezzl et al. (2016) investigated the antenna and maxillary palp of S. tibialis and described the sensilla in these sensorial structures.

The external morphology of the antennae segments of $X$. bipustulata is generally similar to that of other Ulidiidae and calyptrate flies (Sukontason et al. 2006; Carriço et al. 2015; PezzI et al. 2016; CAETANo et al. 2018). In this study, the microtrichia morphology of the antennae is similar to that of other calyptrate and are present on all antennal surface with a variable distribution (SUKONTASON et al. 2004; SUKONTASON et al. 2007; Setzu et al. 2011; Zhang et al. 2013a; Zhang et al. 2013b; CARRIço et al. 2015; Pezzl et al. 2016; CAetano et al. 2018).

The chaetic sensilla were observed in the scape (chl) and pedicel segments (Chl-Chll). This distribution pattern was also found in O. albuquerquei, O. aenescens (CARRIço et al. 2015) and Ophyra chalcogaster (Wiedemann) (SUKONTASON et al. 2007), but differs of S. tibialis, M. bellardiana; M. bicolor and $M$. semihyalina that have tree type of chaetic sensilla (PEzzı et al. 2016; CAETANo et al. 2018).

The flagellum is the largest segment of the antenna and its

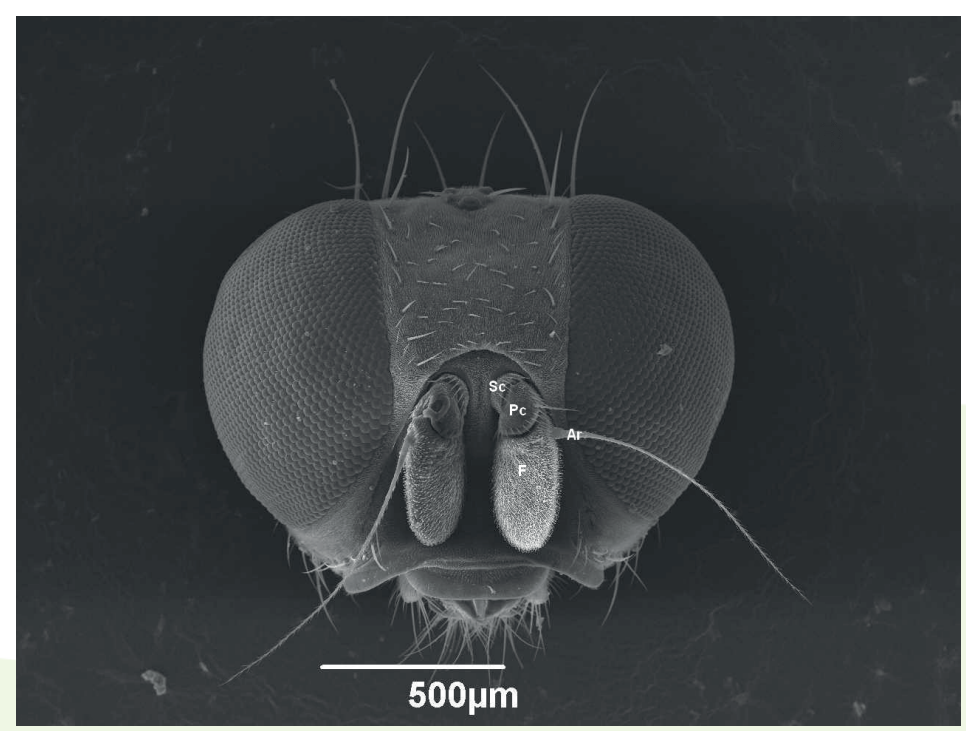

Figure 1. Scanning electron micrographs showing the heads of female, in frontal view, of Xanthacrona bipustulata: female (X 50). Sc = scape; $\mathrm{Pe}=$ pedicel; $\mathrm{Ar}=$ arista; $\mathrm{Fn}=$ first flagellomere . 

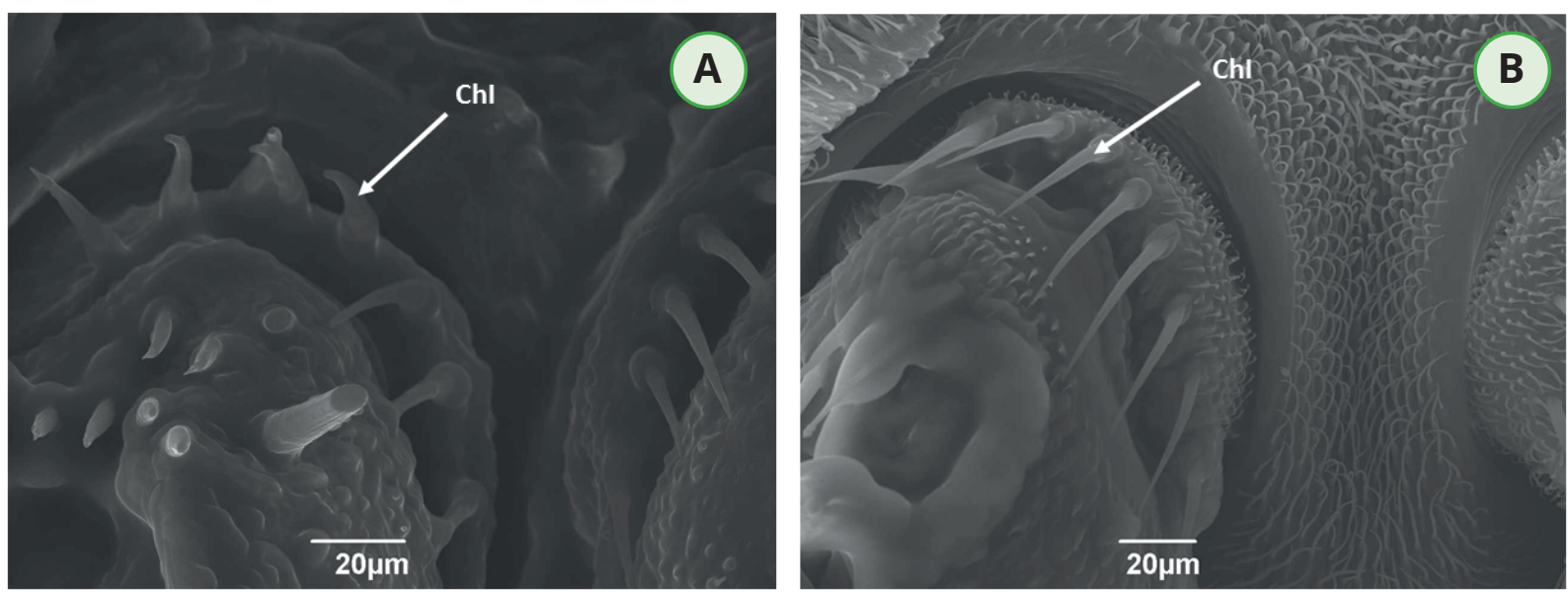

Figure 2. Scanning electron micrographs showing the cuticular surface of scape in both genders of Xanthacrona bipustulata: (A) male (X 800), (B) female (X 650). Sc = scape; Chl = chaetic sensilla.
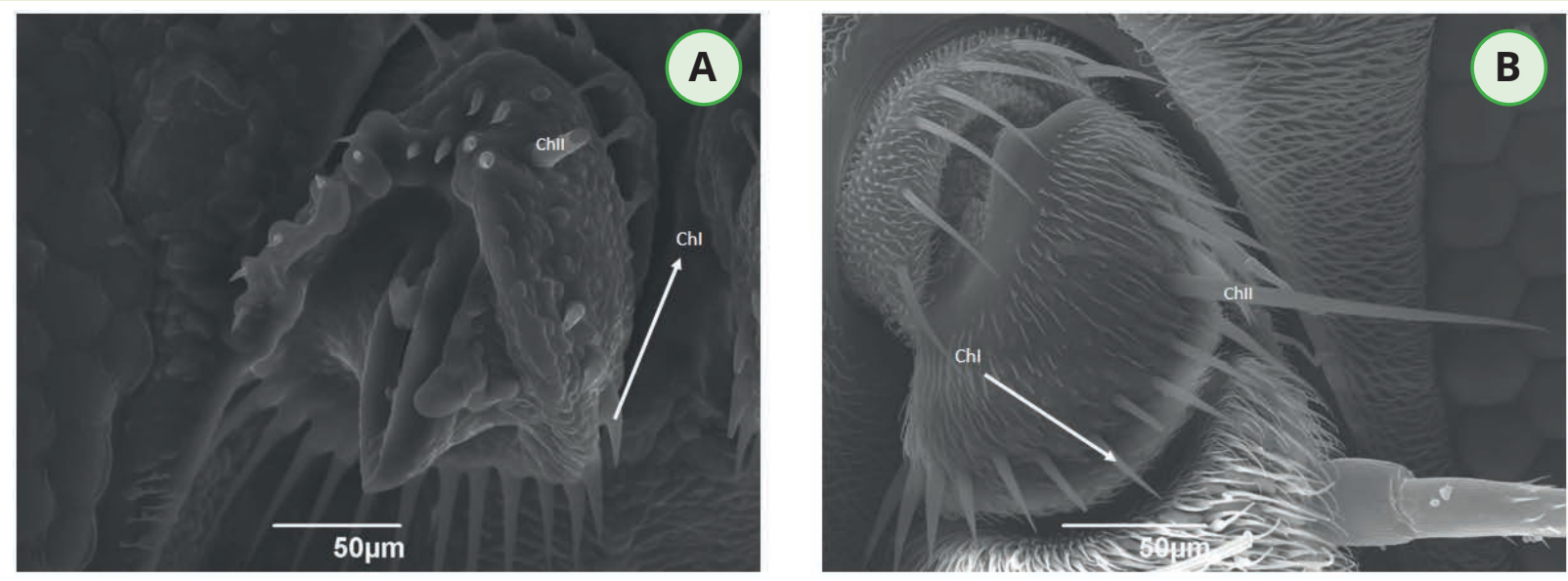

Figure 2. Scanning electron micrographs showing the cuticular surface of scape in both genders of Xanthacrona bipustulata: (A) male (X 800), (B) female (X 650). Sc = scape; Chl = chaetic sensilla.
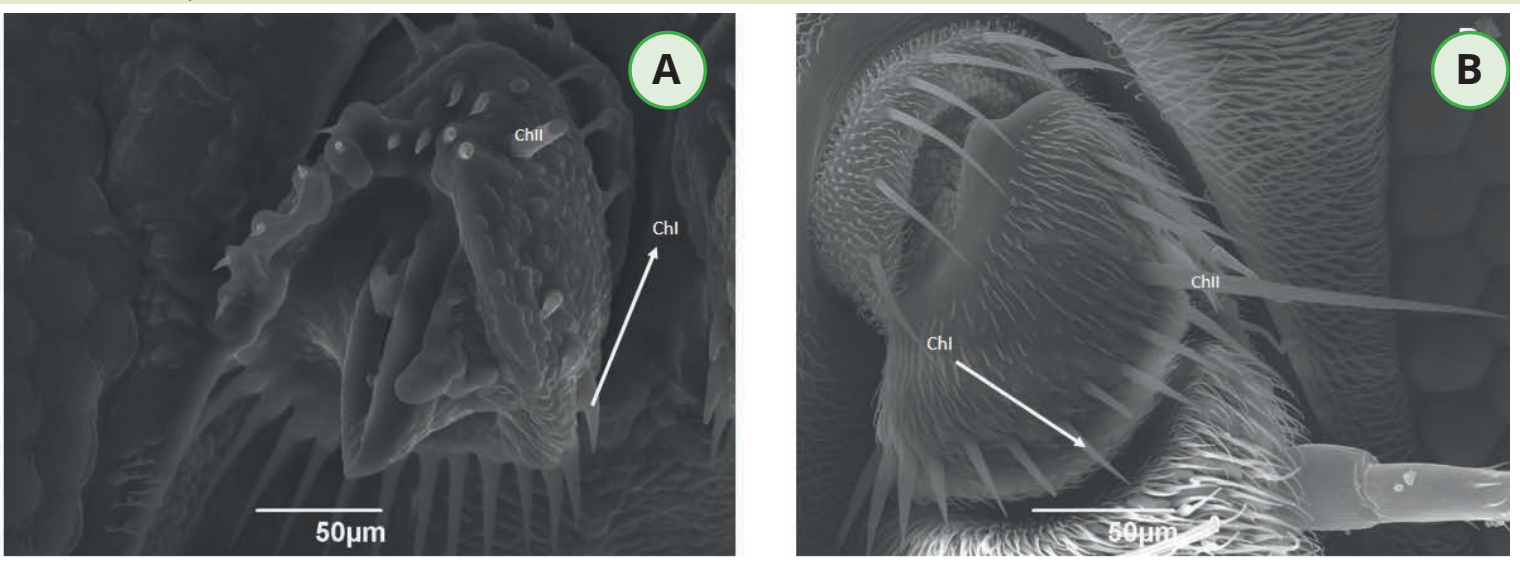

Figure 3. Scanning electron micrographs showing the cuticular surface of pedicel in both genders of Xanthacrona bipustulata: (A) male (X 450), (B) female (X 500). Pe = pedicel; Chl-ChII = chaetic sensilla I and II.
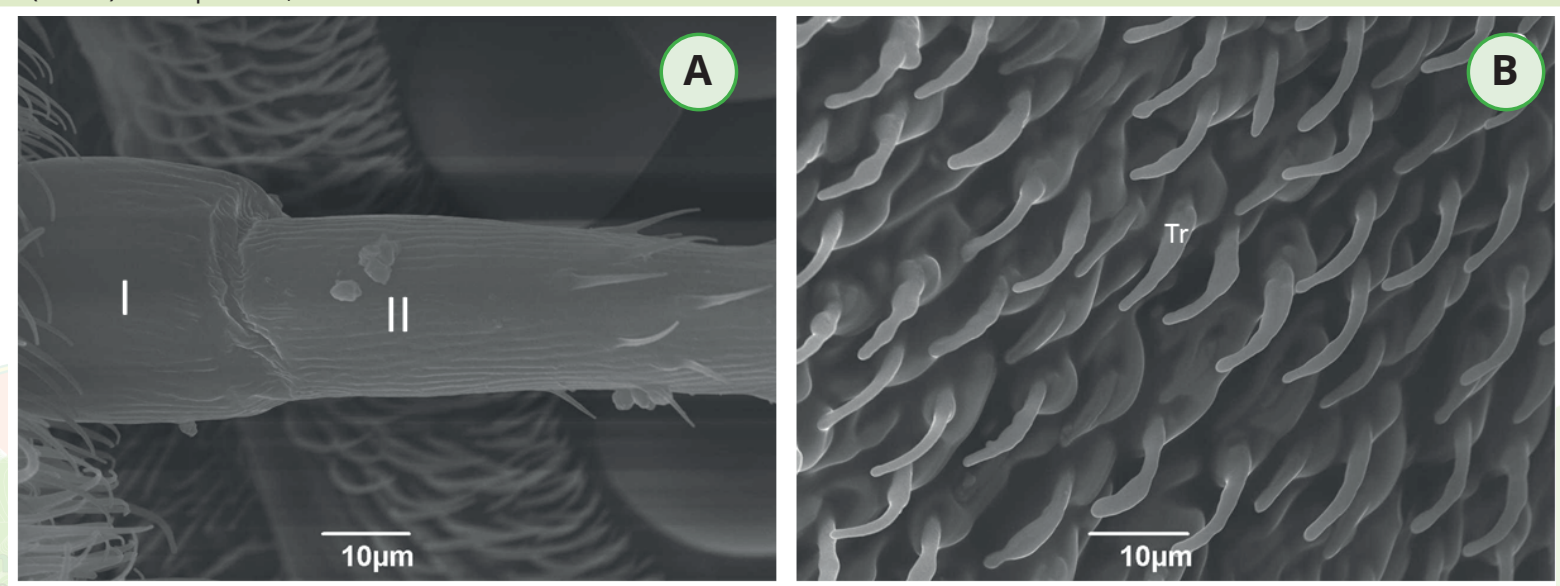

Figure 4. Scanning electron micrographs showing the cuticular surface of flagellum of female Xanthacrona bipustulata: (A) arista of female divided in two (I-II) segments (X 450). (B) Flagellomere (X 1700). Fn = first flagellomere; $\mathrm{Tr}=$ trichoidea. 
number of sensory sensilla can vary from species to species (SukONTASON et al. 2004; CARRIço et al. 2015). One types of sensilla on female was observed: trichoidea (tr); those distribution differ of other dipteran species, such as 0 . chalcogaster (SUKONTASOn et al., 2007), Musca domestica Linnaeus (SUKONTASON et al. 2004), F. scalaris and F. canicularis (Zhang et al. 2013b), L. mongola (ZhANG et al. 2013a) P. terraenovae (SETZu et al. 2011), O. albuquerquei and O. aenescens (CARRIço et al. 2015) and $M$. bellardiana; M. bicolor and M. semihyalina (CAETANO et al. 2018).

In conclusion, taxonomical studies are important to the biological sciences in general, because erroneous species identifications can mislead expert reports, additionally, this investigation provided new findings of some diagnostic structures of flies using SEM, since many of them are not possibly observed just by the use of light microscopy

\section{ACKNOWLEDGEMENTS}

We thank Paulo Vander Ferreira Santana (professor from Prefeitura Municipal do Rio de Janeiro) for language editing. All authors acknowledge the Electron Microscopy Platform Rudolf Barth of Instituto Oswaldo Cruz (IOC/FIOCRUZ) for the use of the scanning electron microscope.

\section{REFERENCES}

Brown, BV, AJ Borkent, M Cumming, DM Wood \& NE Woodley, 2009. Zumbado (eds.). Manual of Central American Diptera. Vol. 2. Ottawa, NCR Research Press.

Caetano, RL, C Carriço, DMA Freitas \& ZT Pinto, 2018. Ultrastructure of sensilla on antennae and maxillary palps in three Mesembrinellidae species. Revista Chilena de História Natural, 91: 1-9. DOI: https://doi.org/10.1186/ s40693-018-0077-6

Carriço, C, PM Mendonça, LB Cortinhas, JRS Mallet \& MMC Queiroz, 2015. Ultrastructural studies of some character of Diptera (Muscidae) of forensically importance. Acta Tropica, 142: 96-102. DOI: https://doi.org/10.1016/j. actatropica.2014.11.005

Carriço, C, RL Caetano, LDR Barbán-Alvarez \& ZT Pinto, 2017. Morphology of Flesh Fly Peckia (Peckia) chrysostoma (Diptera: Sarcophagidae) Revealed by Scanning Electron Microscopy. Austin Journal of Forensic Science and Criminology, 4: 1063. DOI: https://doi.org/10.26420/ austinjforensicscicriminol.2017.1063

Goyal, G, GS Nuessly, DR Seal, JL Capinera, GJ Steck \& KJ Boote, 2011. Distribution of picture-winged flies (Diptera: Ulidiidae) infesting corn in Florida. Florida Entomologist, 94: 35-47.DOI: https://doi.org/10.1653/024.094.0106

Kameneva, EP \& VA Korneyev, 2010. Ulidiidae (Picturedwinged flies), pp. 883-904. In: Brown, BV, A Borkent, JM Cumming, DM Wood, NE Woodley \& M Zumbado (Eds). Manual of Central America Diptera. Boca Raton, NRC Research Press. vol. 2.

Kosmann, C, RP Mello, ES Harterreiten-Souza \& JR PujolLuz, 2013. A list of current valid blow fly names (Diptera: Calliphoridae) in the Americas South of Mexico with key to the Brazilian species. EntomoBrasilis, 6: 74-85. DOI: https://doi.org/10.12741/ebrasilis.v6i1.266

Lopes, O, EN Barata, H Mustaparta \& J Araújo, 2002 Fine structure of antennal sensilla basiconica and their detection of plant volatiles in the eucalyptus woodborer, Phoracantha semipunctata Fabricius (Coleoptera: Cerambycidae). Arthropod Structure \& Development, 31, 1-13. DOI: https://doi.org/10.1016/S1467-8039(02)00011-

Suggestion citation:

Carriço, C, RL Caetano, TMS Nascimento \& ZT Pinto, 2020. Ultrastructural studies of sensilla in one fly of forensic importance. EntomoBrasilis, 13: e849.

Available in: doi: 10.12741/ebrasilis.v13.e849
7

Marchiori, CH, ÂT Oliveira \& AX Linhares, 2001. Artrópodes associados a massas fecais bovinas no Sul do Estado de Goiás. Neotropical Entomology, 30: 19-24. DOI: https://doi.org/10.1590/s1519-566×2001000100004

Mello, RP, 2003. Chave para identificação das formas adultas das espécies da família Calliphoridae (Diptera, Brachycera, Cyclorrhapha) encontradas no Brasil. Entomologia y Vectores, 10: 255-268.

Moretti, TC, OB Ribeiro, PJ Thyssen \& DR Solis, 2008: Insects on decomposing carcasses of small rodents in a secondary forest in Southeastern Brazil. European Journal of Entomology. 105: 691-696. DOI: https://doi.org/10.14411/eje.2008.094

Nascimento, MA, TMF Salomão \& GF Martins, 2013. Estudo comparativo das sensilas antenais de operárias de Melipona scutellaris Latreille (Hymenoptera: Apidae) de diferentes altitudes. EntomoBrasilis, 6: 64-67. DOI: https://doi.org/10.12741/ebrasilis.v6i1.252

Pezzi, M, D Whitmore, M Chicca, B Semeraro, F Brighi \& M Leis, 2016. Ultrastructural morphology of the antenna and maxillary palp of Sarcophaga tibialis (Diptera: Sarcophagidae). Journal of Medical Entomology. 53: 1-8. DOI: https://doi.org/10.1093/jme/tjw061

Setzu, MD, S Poddighe \& AM Angioy, 2011. Sensilla on the antennal funiculus of the blow fly, Protophormia terraenovae (Diptera: Calliphoridae). Micron, 42: 471-477. DOI: https://doi.org/10.1016/j.micron.2011.01.005

Souza, AM \& AX Linhares, 1997. Diptera and Coleoptera of potential forensic importance in southeastern Brazil: Relative abundance and seasonality. Medical and Veterinary Entomology. 11: 8-12. DOI: https://doi.org/10.1111/j.1365-2915.1997.tb00284.x

Sukontason, K, KL Sukontason, S Piangjaia, N Boonchua, $T$ Chaiwonga, R Ngern-kluna, D Sripakdeea, RC Vogtsbergerb \&JK Olsonc, 2004. Antennal sensilla of some forensically importante flies in families Calliphoridae, Sacorphagidae and Muscidae. Micron, 35: 671-679. DOI: https://doi.org/10.1016/j.micron.2004.05.005

Sukontason, K, R Methanitikorn, T Chaiwong, H Kurahashi, RC Vogtsberger \& KL Sukontason, 2007. Sensilla of the antenna and palp of Hydrotaea chalcogaster (Diptera: Muscidae). Micron, 38: 218-223. DOI: https://doi.org/10.1016/j.micron.2006.07.018

Sukontason, KL, N Bunchu, R Methanitikorn, T Chaiwong, B Kuntalue \& K Sukontason, 2006. Ultrastructure of adhesive devise in fly in families Calliphoridae, Muscidae and Sarcophagidae, and their implication as mechanical carries of pathogens. Parasitology Research, 98: 477-481. DOI: https://doi.org/10.1007/s00436-005-0100-0

Tepedino, KP, AC Prestes, C Kosmann, AC Franco, JR PujolLuz \& CVA Pujol-Luz, 2016. Lista das espécies de Ropalomeridae, Sphaeroceridae e Ulidiidae (Diptera, Acalyptratae) do estado de Mato Grosso do Sul, Brasil. Iheringia. Série Zoologia, 107: e2017147. DOI: https://doi.org/10.1590/1678-4766e2017147

Zhang, D, QK Wang, XH Liu \& K Li, 2013a. Sensilla on antenna and maxillary palp of predaceous fly, Lispenei mongola Tian et Ma (Diptera: Muscidae). Micron, 49:33-39. DOI: https://doi.org/10.1016/j.micron.2013.02.012

Zhang, D, QK Wang, YZ Yang, YO Chen \& K Li, 2013b. Sensory organs of the antenna of two Fannia species (Diptera: Fanniidae). Parasitology Research, 112: 2177-2185. DOI: https://doi.org/10.1007/s00436-013-3377-4 **********
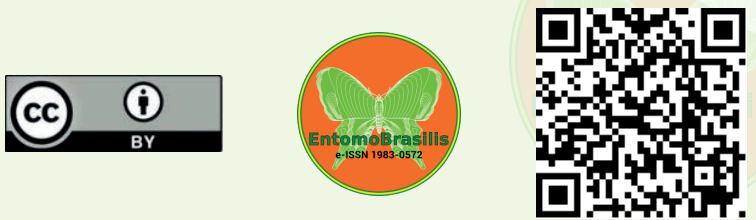